\title{
URBAN ARCHITECTURAL HERITAGE AND SUSTAINABLE TOURISM
}

\author{
KABILA HMOOD ${ }^{1}$, HANAN JUMAILY ${ }^{2} \&$ VLADA MELNIK $^{3}$ \\ ${ }^{1}$ Department of Architecture, Al-Zaytoonah University of Jordan, Jordan \\ ${ }^{2}$ Department of Architecture, Middle East University, Jordan \\ ${ }^{3}$ Department of Architecture, Applied Science Private University, Jordan
}

\begin{abstract}
Tourism is an ancient phenomenon that has developed throughout time; it has changed from a source of entertainment to a source of national income. It reawakens societies culturally, intellectually, and artistically. As a result, developing tourism is a major issue in many countries. Tourist locations are divided into many types, including the archaeological locations that result in heritage tourism, which is considered to be one of the most important components of sustainable tourism. This research tackles an important issue: the absence of clear strategic policies that work on balancing the richness of the architectural and historical heritage in many countries, and the lack of efforts in achieving the optimum utilization of archaeological and heritage sites for developing heritage tourism. This research starts by emphasizing the importance of preserving urban and architectural heritage. Then, it moves to studying the policies used in preserving tourist locations. By applying the descriptive analysis method, it discusses the successful experiences of heritage tourism. Finally, it analyzes these experiences, reaching the conclusions and recommendations. The descriptive analysis method relies on an important research hypothesis; the ideal and efficient use of our cultural heritage is achieved by constructing sustainable restoration of archaeological and heritage sites to achieve sustainable heritage tourism. Everyone involved in investing in it, to enhance its tourist role, should do this. This research benefited from experiments in countries which possess a heritage, in deriving lessons, values and concepts that contribute in achieving an efficient program for the sustainable tourism development, which is based on preserving heritage in the old cities. It must balance between the society's needs, the available resources, the efforts of the executives and the city planning, all while protecting the environment.

Keywords: sustainable tourism, preserving historical sites, architectural heritage, heritage tourism, identity.
\end{abstract}

\section{INTRODUCTION}

Over the last century, tourism has become one of the fastest growing industries in the world and current trends and tendencies indicate that it could become the most important sector in terms of international trading in the 21 st century. Most governments encourage tourism because of its ability to increase and spread economic development thus reducing the inequalities in income distribution by providing and creating employment opportunities.

Tourism has many impacts. Firstly, it has economic impacts, which can be understood at two different levels; the national level and the local level. The positive economic impact of tourism may contribute in, or even provide funds for preserving the historic and /or natural environment and the cultural heritage of the local environments. Secondly, it has a sociocultural impact that creates opportunities for locals to learn and share the cultural traditions of the tourist's indigenous culture and heritage, whilst also arousing concern [1, pp. 99-100]. The World Tourism Organization (WTO) has defines cultural tourism in two ways. In the narrow sense, cultural tourism includes "movements of persons for cultural motivations, such as study tours, performing arts, cultural tours, travel to festivals and other cultural events, visits to sites and monuments, travel to study nature, folklore or art, and pilgrimages." In the broader sense, it is defined as "all movements of persons, motivated by the human need for 
diversity, raising the cultural level of the individual and creating new knowledge, experiences and encounters" [1, pp. 101-103].

\subsection{Sustainable tourism}

The Brandt-land Sustainable Development Authority's definition has increasingly gained international acclaim. The 1978 report of "Our Common Future" has shown that meeting our present needs does not negatively affect future generations. Sustainability refers to "the longterm economic, environmental, and social health". Sustainable tourism is a development model which administrates all of the resources for the economic, social and aesthetical needs of locals and visitors, and provides the same conditions for future generations. Most definitions of sustainable tourism emphasize the environmental, social and economic elements of tourism [1, p. 104]. Sustainable tourism also emphasizes conserving the cultural heritage and traditions of local communities. All the definitions address the preservation of resources for future generations by using tourism to contribute in environmental protection, limiting negative socio-economic impacts, and benefiting local people economically and socially. The WTO defines sustainable tourism as "Tourism development that meets the present needs of tourists and host regions while protecting and enhancing opportunities for the future. In an attempt to manage resources in a way that the economic, social and aesthetic needs can be fulfilled while maintaining cultural integrity, essential ecological processes, biological diversity and life support systems". The term "sustainable tourism" is frequently used in project proposals seeking international assistance [2, p. 24].

\subsection{Heritage tourism}

Heritage tourism embraces both eco-tourism and cultural tourism, with an emphasis on conserving natural and cultural heritage. Tourism depends on the quality of the natural and cultural environment. It includes visits to historic sites, museums and art galleries, and exploring national parks. Environmental preservation concerns have given rise to what is known as green tourism, conservation- supporting tourism, and environmentally aware or environmentally sound tourism. Generally, such tourism favours minimal environmental impact, and is concerned with environmental issues [2, p. 23]. The National Trust for Historic Preservation defines cultural heritage tourism as "travelling to experience the places, artefacts, and activities that authentically represent the stories and people of the past and present". Cultural, historic, and natural resources all make up heritage tourism sites [3].

The relationship between heritage resources and tourism is dynamic, creating opportunities and challenges, and may involve potential conflicts. They should be managed in a sustainable way for present and future generations. Maintaining the authenticity of heritage sites and collections is important. It is an essential element of their cultural significance, as expressed in the physical material, collected memory and intangible traditions that remain from the past. Programs should present the authenticity of places and cultural experiences to enhance the appreciation and understanding of that cultural heritage [2, p. 94].

\subsection{Ecological tourism}

Ecological tourism plays a significant role in the global tourism industry. According to the experts of the World Tourism Organization, in the near future, it will continue to grow rapidly, and the revenue generated will make a significant contribution to the development

of the economies of many countries, especially developing countries. Ecotourism leads to the 
sustainable development of tourism and travel [4]. Rational use of natural and historical tourist resources avoids many of the negative consequences of mass tourism, but the problems of developing ecological tourism have been little investigated. The ecological nature of ecotourism is reflected in preserving the diversity of the flora and fauna of areas. To achieve this, environmental technologies, developed by experience and the scientific recommendations of applied science, are used. The economic and social benefits of ecotourism are enormous. It increases the economic sustainability of territories involved in recreational use by creating new jobs and attracting locals to the service sector, raising their living standards, thus reducing social tension [5]. This definition is similar to the definition of the International Organization of Ecotourism (TIES): ecotourism is "responsible travel to natural areas, areas that preserve the environment and support the well-being of local residents" [6].

\subsection{The importance of preserving urban and architectural heritage}

Many countries, including Arab countries, have tourist attractions that include natural features such as landforms, climate, life, forests and man-made objects, such as parks, museums, archaeological sites [7], which represent the first category of tourist facilities. There are also tourist areas of dual character, which have both natural and historical and features. The architectural oases are great attractions that give modern man the opportunity to have direct contact with the past, in addition to knowing the history of great civilizations [8]. Heritage is a means of education for the local and external community. Many countries, through the UNESCO, provide financial and scientific assistance to save heritage in other countries of the world. Preserving the architectural heritage helps preserve the identity of societies [9]. Many references agree on making the preservation policy of urban and architectural heritage based on two aspects; the first aims to develop and increase the aesthetic and efficiency of the planning units inherited architecturally, while the second is interested in processing the buildings and urban fabric held recently in a manner that does not harm the heritage inventories [10]. The challenge is to find a way towards sustainable tourism development, which balances between the economic benefits and the protection of nature and the cultural identity of the destination areas. Cultural heritage has both a positive economic and social impact; it establishes and reinforces identity, creates harmony among people, and supports culture and helps renew tourism. Heritage tourism increases preservation awareness and ethic.

\section{POLICIES ADOPTED IN THE PRESERVATION OF HERITAGE AND TOURISM INVESTMENT}

The sites and inherited buildings are maintained differently depending on the urban fabric or the individual building state. These levels are; consolidation, reproduction, restoration, preservation, prevention, restoration, maintenance to prevent or stop deterioration [11]. The procedural steps for conservation are as follows:

1. Documentation: It is studying heritage through recording, describing and photographing the landmarks to preserve them. This is done through comprehensive interviews of professionals, as well as building on the literature and scientific references to get additional information. This eases preservation.

2. Study and analysis: It is done by a team of specialists in architecture, history, heritage, interior design, tourism, maintenance, crafts, sociology, economy and law. All these efforts combine to maintain the credibility of the conservation process [12, pp. 66-67]. 
3. Maintenance and restoration: This phase as well as its predecessors relate to the physical aspect of heritage. Restoration works range from minimal maintenance to maximal maintenance so that the model is restored to its previous state and is eligible for the new use by adding all the required supplies, services and repairs [13]. Restoration methods are:

a. Conservative restoration: preserving the historical building and maintaining its authenticity.

b. Redevelopment restoration: returning the building to its original shape without considering it as a piece of antique. The restoration must be part of the rehabilitation in order to use it in the future [14].

4. Choosing the appropriate function for rehabilitation: Many difficulties appear at this stage because it relates to multiple aspects, thus a good choice must be made. The selection of the new function is based on the location of the model, its architectural value, its original function, spaces distribution, size, and ownership.

5. The modification of spaces according to the new function: It is achieved by changing the interior and urban spaces by employing elements in accordance with the traditional and modern requirements [15].

\section{HERITAGE TOURISM EXPERIENCES}

There are many successful experiments for preserving heritage, including one of the most famous khans in Baghdad, Murjan Khan. It was rebuilt by the Department of Antiquities and Heritage and reused as an Islamic arts museum. Nowadays, Murjan Khan is an outstanding tourist restaurant. It is known for the beauty of its architecture, design, and brick ornaments. It consists of two floors; the first has 22 rooms and the second has 23 rooms. The roof consists of eight huge arches. It includes a series of walls and graded vaults with different shapes and dimensions interspersed by windows. This style helps provide natural lighting. It also reduces the amount of pressure caused by the weight of thearches (Fig. 1) [16].

In $1156 \mathrm{AH}$, the Damascus governor built As'ad-Basha Khan (1743 AD). It served as a hotel, a reception for traders to conduct trades and as warehouses for goods. Recently, the hotel was possessed by the Syrian General Directorate of Antiquities which rebuilt it (Fig. 2). Contemporary exhibitions are currently held in the Khan. It is closed and has a ceiling opening in the center for lighting, ventilation and reduction of moisture. It consists of eight domes. The following figures show both buildings before and after the rebuilding [12, $\mathrm{p}$. 320].

The Khan is located to the south of the Umayyad Mosque within the bazaar market. Bazuriya market is aligned with Medhat Pasha Street in the northern direction [17].
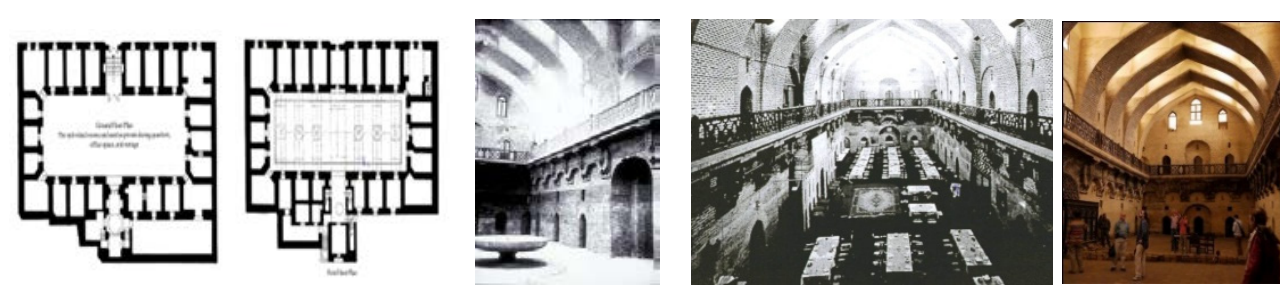

Figure 1: The restoration and rehabilitation stages of Murjan Khan, its plans and great arches. (Source: Hmood, 2011.) 

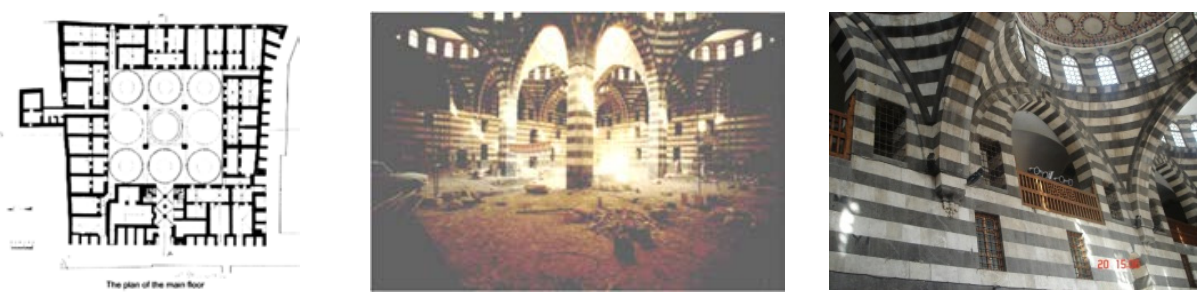

Figure 2: The plan of As'ad Basha Khan. An old picture and a recent one. (Source: Hmood, 2011.)

Another example is the Izmeet archaeological hotel, founded in 1816 in Tripoli, Libya. Since its establishment in the first Ottoman era, it was used as a hotel and a forum for caravan traders between Europe and North Africa. It is located in Bab El Bahr, near the port of Tripoli, not far from the Roman Arcos Aurelius arch. It consists of two floors,andisentirely furnished with traditional handmade pieces [18]. The Consulate of Tuscany occupied a building built in the second half of the 18th century under the reign of Ali Pasha al-Qara Manli. It is one of the most beautiful houses in Tripoli. In Ottoman II, it was reused as the Consulate of Tuscany. It was renovated in 1994 to be a building for popular collections and historical costumes, known as the "Tripoli Historic Exhibition of Popular Acquisitions and Historical Fashions" [19] (Fig. 3).

The al-Azem Palace, one of the most impressive secular buildings in Syria, was erected in the XVIII century and originally served as the residence of the governor. Later, it became the Museum of Art and Folk Traditions of Syria. It was built in the traditional eastern style; it is divided into female and male halves, the formal area, baths and outer buildings. Its interiors are animated by genre scenes in which wax dolls participate [20] (Fig. 4).
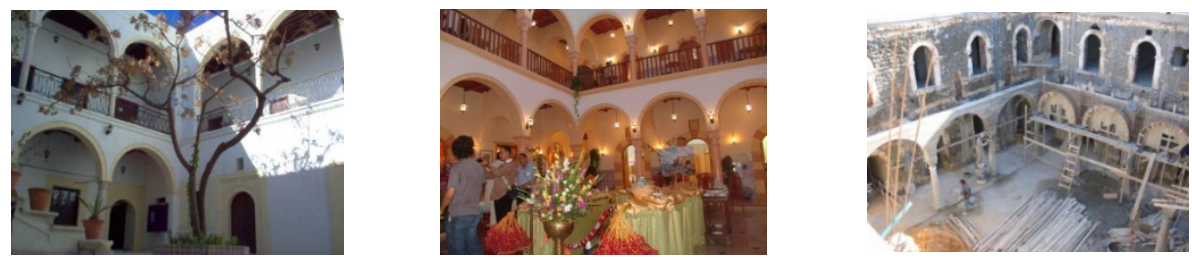

Figure 3: Consulate of Tuscany Izmeet archaeological hotel, some traditional buildings in tripoli. (Source: Hmood, 2011.)
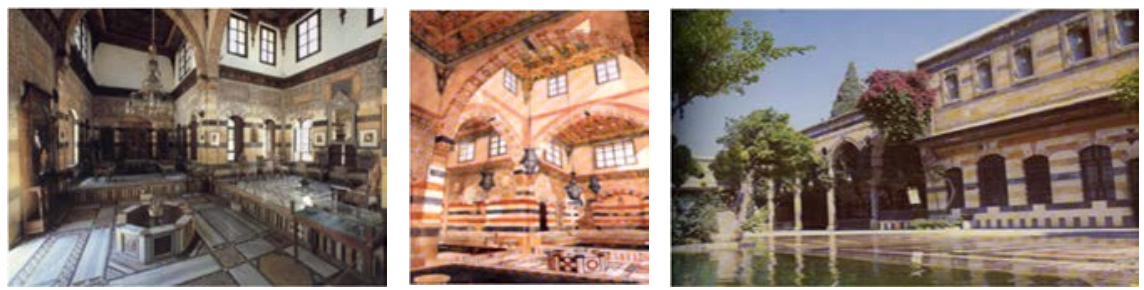

Figure 4: Al-Azem Palace in Damascus. (Source: Melnik, 2007.) 
In the city of Sousse, one could witness the preservation of the old and corresponding to it by constructing new buildings using the same materials, architectural style and height. The old was separated from the modern by a space. This represents the concept of "dual cities"; the old parts preserve their architectural style while the modern areas are developed. Accordingly, urban conservation in historical cities, can be achieved by applying urban renewal policies which maintain the urban fabric and structure of the inherited city, along with the modern demands [21]. It can be noticed in the city of Ulus, Ankara, Turkey, that the urban structure and roads network were used while maintaining unique buildings and limiting vehicle entrance times. This is done by preserving its heritage without adding modern elements, and applying rehabilation, which meets the modern needs of the residents (Fig. 5).

Many policies confirm that the orientation is necessary to link the old with modern planning projects in a unified architectural way. That is due to the incapability of separating between the old urban fabric and the modern constructive situation. Both fabrics; the old and new, make up the entire urban structure of the Arabic city. The village of Taybeh Zamanis, located several kilometers from the city of Petra, Jordan, was a residence for the inhabitants of the town during the Middle Ages until the beginning of the 20th century. The residents of the village left their old homes and developed it to a tourist resort serving visitors to the city of Petra (Fig. 6). The company has restored its its alleys, squares and houses to as they were in the past.The simple rooms where the villagers lived were changed into hotel rooms. In addition, some of the corridors, old houses and stores were transformed to reception halls, administration rooms and other tourist services facilities such as restaurants and multipurpose meetings halls. Furthermore, some areas were changed to shops which include films, photography studios, antiques, souvenirs, handicrafts, etc. These shops carry traditional names associated with village life.

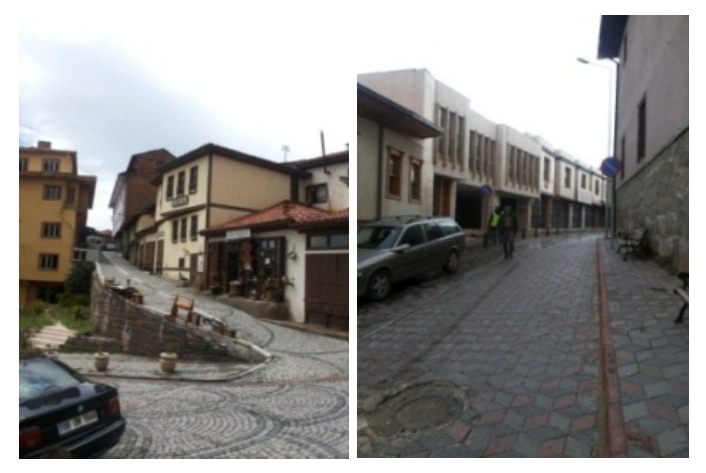

Figure 5: Ulus, Turkish capital, Ankara, and the urban conservation of its structure and roads in a way which adapts with the old. (Source: Hmood; 2014.)
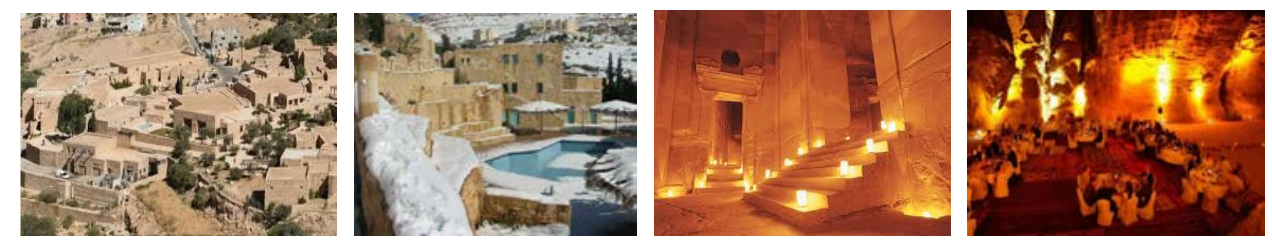

Figure 6: Taibah Zaman resort and art of lighting to attract tourists. (Source: Gulf Tourism in Jordan, 1999.) 
The Taibah Zaman Resort is a unique one-storey resort with a huge area to accommodate tourists. 99\% of the workers in Taibah Zaman are villagers who have been trained in tourism. The village consists of narrow alleys, arches, courtyards, and stone houses which were built decades ago. The feeling of rural life is strengthened because it is surrounded by beautiful valleys, rocks, parks and trees that have remained in their primitive state. It is the first eco-friendly Jordanian resort [22]. Artificial lighting is used at night to illuminate the entire village. As a result, the village shines in the distance.

\section{ANALYTIC STUDY}

\subsection{Um Qais}

Tourism development can put pressure on natural resources, especially in areas where resources are already scarce. Um Qais is an ancient city of the Greco-Roman Decapolis, formerly known as Gadara. In Evangelia, it is mentioned as the place where Christ preached, and where He performed the miracle of exorcism of demons from the possessed. The modern city is on the border of Jordan, Palestine and Syria, almost along the shore of the Genisaret (Tiberius or Galilee) lake [23]. The ancient city is well preserved and is a popular tourist destination. On its outskirts are the ruins of the ancient city of Gadara. Scientists cannot specify the exact date of its construction by the Greeks, but the era of its heyday came simultaneously with the arrival of the Romans. In 30 BC, Emperor Augustus presented the city to the cruel king of Judea, Herod the Great. The remains of the Byzantine temple show the skill of the ancient builders. The Western Theatre, perfectly inscribed in the mountain slope, seated three thousand spectators. The development of Gadara was not stopped by wars, insurrections, or punitive expeditions. The main issue for the city became natural forces. In 748 , Gadara was devastated by an earthquake. Only after a thousand years, people began to settle again [24]. While touring the city, one can see the Acropolis, the North Theatre, Column Street, and the Octagonal Basilica. The first rows of the Western Theatre are equipped with stone chairs; they were intended for high-ranking persons. Opposite the Basilica are the ruins of Nymphaeum. From here one can see a wonderful view of the Jordan River, Yarmuk, the Golan Heights and the Tiberius Lake. Not far from the theatre are the baths and the largest family crypt in Jordan (Fig. 7). Above the Western Theatre is a museum of found artefacts. In the courtyards there are tombs, statues and other large exhibits, while the small exhibition stake place in the museum. From the hills of Gadara, one can find the amazing view of the northern part of the Jordan Valley, the Tiberius Lake (Galilee Sea), the Yarmuk River, the Golan Heights and the snow-capped summit Mount Hermon (Jebel Sheikh), Mount Nebo, and the site of the death of Prophet Moses, from where God showed him the Promised Land.

The Moses Memorial can be seen in the place of the ancient sanctuary, which displays mosaics of the 6th century and the famous sculpture of the Italian Fantoni, symbolizing the greatness of God and the staff of Moses [25].
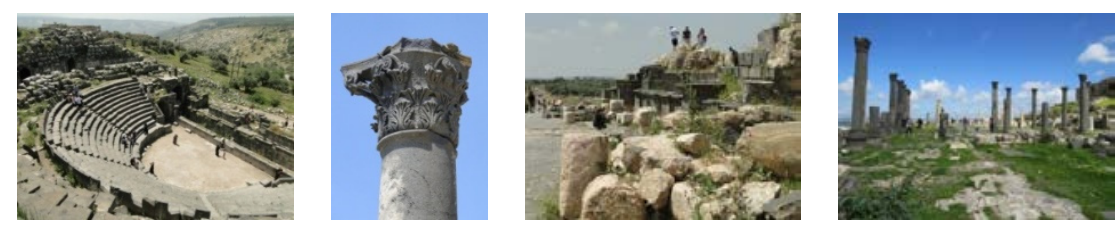

Figure 7: Um Qais. (Source: Melnik, 2015). 


\subsection{The Petra}

Taking advantage of the successful revival of the Taiba Zaman resort to activate tourism in this area, it is important to make it an attraction by artificial lighting at night. Petra, also known as the "Pink City", is an ancient city located in Ma'an Governorate in the southern part of the Hashemite Kingdom of Jordan. It is famous for its stone-carved architecture and ancient water-drainage system. Petra was founded in $312 \mathrm{BC}$ as the capital of the Nabatean kingdom. It held an important status for many years. Its location on the Alharrir Road,which is located in the middle of the Mesopotamian, Palestine and Egypt civilization, played a major role in developing the Nabataeans' trade between the civilizations of these regions.Petra remained undiscovered throughout the Ottoman period until it was rediscovered by the Swiss orientalist Johann Ludwig Berckhart in 1812. It was listed on the UNESCO World Heritage List in 1985. It was also chosen as one of the new Seven Wonders of the World in 2007. Today, Petra is a symbol of Jordan, and is the most attractive tourist destination in the Kingdom.

\subsubsection{Description of the treasury façade of Petra (Al Khazna)}

Al Khazna's rock-carved building is one of the most important landmarks of Petra. It is the first landmark the visitor faces after entering the city. It is composed of two stories with a width of 25 meters and a height of 39 meters. The ground floor consists of six columns along the front façade with a height of 12 meters. The columns on the upper floor are 9 meters high, and are crowned with a triangle that is 3.5 meters high. The building façade's elements composition parallels Nabataean architecture, combining both Hellenistic and Egyptian architecture. The Al Khazna building consists of three rooms, two on the side and one in the center, which is 12.5 meters in length and on its three sides are small burial chambers [26].

\subsubsection{The effect of artificial lighting on tourist monuments}

This research studies the suitable method to activate tourism in Petra at night by taking the treasury façade of Petra as an example for evaluating the effect of artificial lighting on reviving the distinctive architectural elements of that period. Artificial lighting plays gives a sense of place because it emphasizes the façade features depending on its location, intensity, direction and color. It plays an important role in the changing the forms characteristics to create different visual images and aesthetic impressions in the eye and mind. This highlights the design philosophy of that period, which, in turn, affects the visual communication between the tourist and the building's façade. The lighting should be in harmony with the architectural features of the monument, so that it can make it the center of attention for tourists. One of the first experiences of lighting shows was in the Palace of Versailles in France. It reflects three centuries of French history.It was also used in the pyramids and the temple of Karnak in Luxor, Egypt. The lighting shows turn the visitor into a witness of the civilization of that historical building's period. It allows seeing the decorative details of historical and architectural importance which cannot be observed clearly in the daylight. As a result, the tourist senses the spatial and temporal environment in a better way, thus attracting him/her. Lighting patterns vary, and have a great impact in illustrating the architectural elements of the Petra treasury façade (Table 1).

Based on Table 1, and by studying the light patterns used to light the treasury's façade, one can conclude that the mixed lighting (dotted and linear) gives a sense of harmony between the façade's components. It gives dominance to a particular functional element in it. It also attracts the spectator's attention to the beauty of particular aesthetic elements. 
Table 1: The impact of different artificial lighting patterns on reviving symbolic and visual elements of the Petra treasury façade. (Source: Aljumaily Hanan, 2017.)

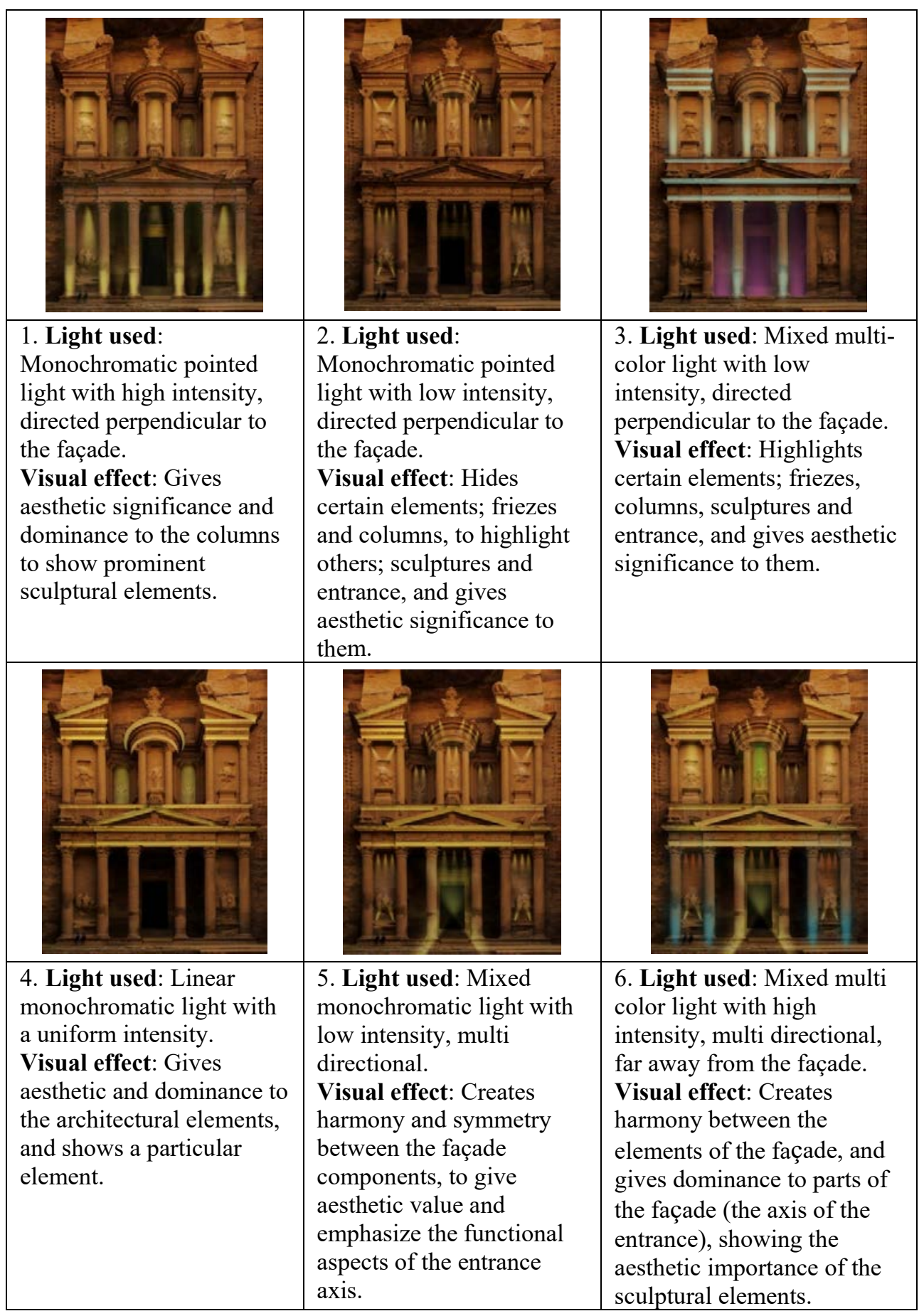


Therefore, mixed-source lighting is the best for creating visual connection between the tourist and the archaeological monument (as shown in Table 1, 3-6).

Using light in different directions and angles creates visual continuance and attracts the tourist's attention towards certain structural elements in the façade; therefore, exciting the tourist's visual sense as shown in (2-6) from Table 1. In addition, using monochromatic colors gives emphasis and dominance to certain elements as shown in (1-5), while using multi-color lighting confirms the color hierarchy used to reflect the importance if each architectural element $(3,6)$.

\section{CONCLUSION AND RECOMMENDATIONS}

The efficient use of our cultural heritage is accomplished by restoring archaeological and heritage sites to achieve sustainable heritage tourism and preserving their identity. According to Webster's Ninth New Collegiate Dictionary (1983), identity is "The distinguishing character or condition of a person or a thing". It must balance between the society's needs, the available resources, the efforts of the executives and the city planning, while protecting the environment during the development of tourist investment.

Sustainable tourism also preserves the heritage and traditions of local communities.

The archaeological sites are maintained at different levels depending on the urban fabric or the individual building's state. These levels are briefly summarized as consolidation, reproduction, restoration, preservation, prevention, restoration, and maintenance steps taken to prevent or stop deterioration.

Although the typology of Arabic buildings is flexible and easily allows rehabilitation, few attempts were made to find modern uses for them.

Tourism development and archaeological sites should be connected by utilizing the traditional urban fabric for modern purposes, while providing first-class tourism services. This introduces the world to these sites and confirms the importance of incorporating historical heritage sites with tourism development. The recommendations are as follows:

1. Applying a system that motivates residents to participate in heritage preservation programs and gives them financial aids.

2. Traditional cities should have a group that is responsible for surveillance and stopping trespassing. This could be done with the cooperation of organizations, such as the UNESCO, The Arabic Cities Organization, and the Agha Khan Foundation by holding annual scientific seminars in which the issues of maintenance and preservation are discussed.

3. Reviewing vehicle motion paths.

4. Acquiring the support of the people and making them a part of the preservation and development processes. Job opportunities and investments should be provided to them, thus, balancing between the society's needs, the available resources, and city planning.

5. It is important to encourage tourism in archaeological and heritage sites, enabling the local residents to feel that they are financially benefiting from it, and that their cultural property is worthy of maintenance and preservation because it is part of the world heritage.

6. An environmental tourism plan that prevents the deterioration of natural, historical and traditional elements must be made, while providing the necessary means for maintenance, and guarantee their preservation for as long as possible.

7. Technology, such as artificial light, should be used in reviving archaeological sites day and night. This is done through making advanced scientific studies on the use of light, which improves the monuments image, and allows the tourist to remain for a longer 
period of time. The researcher's analytic study of Petra proves that artificial lighting plays a major role in reviving heritage tourism, especially at night.

8. Many aspects should overlap in order to achieve a successful preservation experience. These aspects include the plan, design, construction, maintenance, environment, infrastructure, and the laws and policies of tourism. The media should participate to create an awareness of the city's cultural and historical value.

\section{REFERENCES}

[1] Vehbi, B.O., A model for assessing the level of tourism impacts and sustainability of coastal cities. Strategies for Tourism Industry - Micro and Macro Perspectives, eds M. Kasimoglu \& H. Aydin, InTech Europe: London, 2012.

[2] Pedersen, A., Managing Tourism at World Heritage Sites: A Practical Manual for World Heritage Site Managers, UNESCO World Heritage Centre: Paris, 2002.

[3] Waheeb, M. \& Zuhair, Z., Reviving the Past into the Future, Amman Nymphaeum Background and Architecture; The Amman Nymphaeum, Department of Antiquities, http://en.wikipedia.org/wiki/Heritage_tourism. Accessed on: 28 Mar. 2018.

[4] Hall, M.C., Trends in Ocean and Coastal Tourism: The End of The Last Frontier? Ocean \&Coastal Management, 44, pp. 601-618, 2001.

[5] D'Onghia, A.M., Brunel, S. \& Valentini, F., Xylella fastidiosa and the Olive Quick Decline Syndrome (OQDS): A serious worldwide challenge for the safeguard of olive trees. http://om.ciheam.org/om/pdf/a121/a121.pdf. Accessed on: 28 Mar. 2018.

[6] Sunlu, U., Environmental impacts of tourism. Local Recourse and Global Trades: Environments and Agriculture in the Mediterranean Region, eds D. Camarda \& L. Grassini. CIHEAM: Bari, pp. 263-270, 2003.

[7] Hormuz, N., Economic and legal sciences series. Tishreen University Journal for Studies and Scientific Research, 28(3), p. 15, 2005.

[8] Abdul, N. \& Saleh, W., Adopted in Tourism and Antiquities, National Book House: Benghazi, Libya, pp. 12-17, 2006.

[9] Ibrahim, M.A.A., Preservation of heritage national and cultural requirement; Architectural Scientific Journal, Faculty of Architecture, 4th Issue, p. 25, 1988.

[10] Ouf, A.M.S., Urban Conservation Concepts for the New Millennium in the United Arab Emirates, Zayed Center for Heritage and History: Abu Dhabi, pp. 34-37, 2000.

[11] Fitch, J.M., Historic Preservation: Curatorial Management of the Built World, McGraw Hill: New York, p. 8, 1982.

[12] Hmood, K., Urban and Architectural Arab Innovations, Dar al-Warraq: Amman, Jordan, 2011.

[13] Hmood, K., Successful experiments in the preservation of heritage. Proceedings of the Scientific Symposium: Towards a Comprehensive Strategy for the Development and Maintenance of Historical Cities, Ghadames, Libya, 27-29 Oct., p. 89, 2007.

[14] Feilden, B., Introduction into Conservation, UNESCO Press: Rome, p. 2, 1997.

[15] Norberg-Schulz, C., Existence, Space and Architecture, Praeger: New York, p. 10, 1991.

[16] Joseph, S., The History of the Art of Iraqi Architecture in Different Areas, The Ministry of Culture and Information: Baghdad, pp. 522-527, 1982.

[17] Arqawi, A., The historical development of Khan Asaad Pasha Al Azem. Damascus University Journal of Engineering Sciences, 22(1), 2006. www.damascusuniversity. edu.sy/mag/eng/images/stories/1-2006/373-397.pdf.

[18] Talbisi, K., The Story of the City of Tripoli with Arab and Foreign Travelers, Book House: Libya, p. 66, 1994. 
[19] Hashemi, E., Urban character of old Tripoli. Conservation of Old Cities, ed. S. Khalil Al-Qaziri, Organization of the Old City of Benghazi: Libya, pp. 70-75, 2007.

[20] Melnik, V.V., The architecture of the traditional house of Damascus of the late XIXearly XX centuries, Thesis on WAC 18.00.01, 2007. www.dissercat.com/content/ arkhitektura-traditsionnogo-zhilogo-doma-damaska-kontsa-xix-nachala-xx-vekov \#ixzz53Pb8dVEy.

[21] Cohen, N., Urban Planning Conservation and Preservation, McGraw-Hill: New York, p. 17, 2011.

[22] Gulf Tourism in Jordan, Tayba Zamman Tourist Resort restores the intimacy of rural life. Gulf Tourism in Jordan, 13242, p. 20, 1999.

[23] Weber, T., Umm Qais Gadara of the Decapolis. A Brief Guide to the Antiquities. Amman Al Kutba, pp. 15-208, 1990.

[24] Wagner-Lux, U. \& Vriezen, K.J.H., A preliminary report on the excavations at Gadara (Umm Qais) in Jordan from 1976 to 1979. ADAJ, 24, 1980.

[25] Hoffann, A. \& Kerner, S., Gadara-Gerasa and Decapolis, Verlag Philipp von Zaben: Mainz, 2002.

[26] Aljumaily, H.M. \& Alshaikhly, N., The effect of light projection on historical building façades. Proceedings of the Third International Conference, Art and Identity between Heritage and Contemporary, pp. 105-106, 2017. 